\title{
HUBUNGAN KEPATUHAN CUCI TANGAN DAN PENGGUNAAN APD PERAWAT DENGAN RESIKO KEJADIAN HEALTHCARE ASSOCIATED INFECTIONS (HAIS) PADA MASA PANDEMI COVID-19 DI RSUD MAYJEND. H.M. RYACUDU LAMPUNG UTARA
}

\author{
Eka Novita Sari ${ }^{1}$, M. Ricko Gunawan ${ }^{2}$, M. Arifki Zainaro ${ }^{3^{*}}$
}

\author{
${ }^{1}$ Mahasiswa Program Studi Keperawatan Universitas \\ MalahayatiEmail : ekanovitasarii98@gmail.com \\ ${ }^{2}$ Dosen Program Studi Keperawatan Universitas \\ MalahayatiEmail : muhrickogunawan@gmail.com \\ ${ }^{3}$ Dosen Program Studi Keperawatan Universitas \\ MalahayatiEmail :m.arifkiz@yahoo.com
}

Disubmit: 19 Agustus 2021 Diterima: 31 Desember 2021 Diterbitkan: 01 Januari 2022 DOI: https://doi.org/10.33024/mnj.v1i1.4857

\begin{abstract}
RELATIONSHIP OF HAND WASHING COMPLIANCE AND NURSE PPE USE WITH RISK OF HEALTHCARE ASSOCIATED INFECTIONS (HAIS) DURING THE COVID-19 PANDEMIC AT RSUD MAYJEN H.M. RYACUDU NORTH LAMPUNG
\end{abstract}

Introduction : Infection is the invasion of the body by a pathogen or microorganism, which can cause disease or tissue damage. A hospital infection or hospital-acquired infection (HOIS) or health care-associated infection (HAIS) is an infection acquired during a patient's hospital stay, provided that the incubation period of the disease has not occurred at the time of admission.

Objective : It is known that there is a relationship between handwashing compliance and the use of PPE for nurses with the risk of healthcareassociated infections (HAIS) during the COVID-19 pandemic at the Mayjend.H.M Ryacudu Hospital, North Lampung in 2021.

Methods : The type of research used in this study is related to the descriptive nature with a cross sectional research design. The subjects of this study were all obstetrical, pediatric (perinatal and NICU) nurses, operating rooms and internal medicine at Mayjend.H.M Ryacudu Hospital, North Lampung. The number of samples used as many as 60 respondents.

Results : The statistical test of nurses' compliance with the chi-square in hand washing obtained a $p$ value of 0.033 where the $p$ value $<(0.033<0.05)$ then $\mathrm{Ha}$, and the Oods Ration value was accepted at 0.314. By using the chi-square statistical test for nurses who use PPE, the $p$-value is 0.241 , so the $p$-value < $(0.241>0.05)$ and $\mathrm{Ho}$ is rejected, and the Oods ration value is 0.519 .

Conclusion : There is a relationship between hand washing compliance with the risk of health-related infections (HAIS), and there is no relationship between the use of PPE by nurses and the risk of healthcare-associated infections (HAIS) at the Mayjend H.M Ryacudu Hospital, North Lampung.

Keywords: Compliance with hand washing, use of APD, HAIS 
INTISARI : HUBUNGAN KEPATUHAN CUCI TANGAN DAN PENGGUNAAN APD PERAWAT DENGAN RESIKO KEJADIAN HEALTHCARE ASSOCIATED INFECTIONS (HAIS) PADA MASA PANDEMI COVID-19 DI RSUD MAYJEND. H.M. RYACUDU LAMPUNG UTARA

Pendahuluan : Infeksi adalah invasi tubuh oleh patogen atau mikroorganisme, yang dapat menyebabkan penyakit atau kerusakan jaringan. Infeksi rumah sakit atau infeksi yang didapat di rumah sakit (HOIS) atau infeksi terkait perawatan kesehatan (HAIS) adalah infeksi yang diperoleh selama pasien dirawat di rumah sakit, asalkan masa inkubasi penyakit belum berlangsung pada saat masuk.

Tujuan : Diketahui hubungan kepatuhan cuci tangan dan penggunaan APD perawat dengan resiko kejadian healthcare associated infections (HAIS) pada masa pandemi covid-19 di RSUD Mayjend.H.M Ryacudu Lampung Utara.

Metode : Jenis penelitian yang digunakan dalam penelitian ini berkaitan dengan sifat deskriptif dengan desain penelitian cross sectional. Subyek penelitian ini adalah seluruh perawat obstetri, anak (perinatal dan NICU), kamar operasi dan penyakit dalam di RSUD Mayjend.H.M Ryacudu Lampung Utara. Jumlah sample yang dipakai sebanyak 60 responden.

Hasil : Uji statistik kepatuhan perawat terhadap chi-square dalam cuci tangan diperoleh nilai $\mathrm{p}$ sebesar 0,033 dimana nilai $\mathrm{p}<\mathrm{a}(0,033<0,05)$ kemudian $\mathrm{Ha}$, dan nilai Oods Ration diterima sebesar 0,314. Dengan menggunakan uji statistik chi-square perawat yang menggunakan APD didapatkan nilai p-value 0,241, sehingga nilai $p$-value $<a(0,241>0,05)$ dan Ho ditolak, serta nilai Oods ration sebesar 0,519.

Kesimpulan : Memiliki hubungan antara kepatuhan cuci tangan dengan risiko infeksi terkait kesehatan (HAIS), serta tidak ada hubungan antara penggunaan APD oleh perawat dengan risiko healthcare associated infections (HAIS) pada RSUD mayjend H.M Ryacudu Lampung Utara.

Kata Kunci : Kepatuhan cuci tangan, penggunaan APD, HAIS

\section{PENDAHULUAN}

Masalah kesehatan yang

saat ini sedang ramai diperbincangkan di dunia adalah penyakit covid19. Covid19 disebabkan oleh virus yang sekarang disebut penyakit coronavirus 19 atau lebih umum Covid19. Covid-19 adalah penyakit menular yang dapat disebabkan oleh Severe Acute Respiratory Syndrome Coronavirus 2

(SARSCoV2). SARSCoV2 adalah jenis virus baru yang belum pernah ditemukan pada manusia sebelumnya. (Anggreni, D., \& Safitri, C. A. 2020; Fitriyana, N. 2020; Wahyuni, D., Sururuddin, S., \& Nugroho, A. S. 2021).
Coronavirus adalah partisi, sehingga virus dapat berasal dari hewan dan menyebar ke manusia. Penularan ini biasanya terjadi melalui kontak droplet dengan virus, dan kemudian virus dapat masuk ke dalam mukosa yang terbuka. Penularan diisolasi berdasarkan masa inkubasi, gejala, dan durasi gejala antar pasien. Berdasarkan klasifikasi terbagi menjadi beberapa kasus terduga (suspect case), kasus probable (probable case), kasus terkonfirmasi (Handayani, D., Hadi, D. R., Isbaniah, F., Burhan, E., \& Agustin, H. 2020; Hasanah, R. 2020; Amin, M., Saleh, A. M., \& Bilfaqih, H. Z. A. 2020). 
Rumah sakit adalah tempat dimana orang mendapatkan pelayanan dan perawatan kesehatan yang baik, termasuk tempat dimana mereka menginginkan pengobatan yang terbaik. Banyak pasien terjangkit penyakit ini setelah masuk, yang tentu saja menambah penderitaan dan biaya pasien bahkan berujung pada kematian. Infeksi ini umumnya dikenal sebagai infeksi terkait perawatan kesehatan (HAI). Healthcare-related Infections (HAI) merupakan salah satu masalah kesehatan di negara-negara di dunia, termasuk Indonesia. (Purnomo, M., Siswanti, H., \& Prayitno, A. 2019; Trisnantoro, L. 2018; Indarta, D. W. (2019).

Menurut laporan World Health Organozations (WHO) sekitar 5\% dari seluruh pasien dirumah sakit menderita infeksi nosokomial. Berdasarkan WHO dari 55 rumah sakiit dari 14 negara mewakili wilayah kerja WHO menunjukan frekuensi tertinggi infeksi nosokomial berada dirumah sakit di Asia Tenggara atas prevalensi $11 \%$, serta di Indonesia kejadian mencapai $15.74 \%$ lebih besar dibandingkan negara maju berkisar 4.85 - 15.5\%. Kejadian infeksi nosokomial sering terjadi yakni ISK 40\% dari seluruh kejadian dapat terjadi setiap tahunnya (Amelia, R. A., Winarto, W., Hadi, P., \& Lestari, E. S. 2020).

Mencuci tangan sangat
berperan penting didalam pencegahan infeksi nosokomial, tetapi juga perlu memperhatikan tingkat kepatuhan akan pelaksanaan cuci tangan. itu sendiri. Tingkat kepatuhan perawat didalam cuci tangan dirumah sakit India 53.4\%, dokter 42.5\%, serta petugas kesehatan lainnya 32.6\%. Berdasarkan tingkat kepatuhan cuci tangan dirumah sakit Bandung sebesar $48.3 \%$. Semarang kepatuhan cuci tangan rendah sebanyak
25.92\%, Malang kepatuhan cuci tangan sebesar $19.5 \%$ serta meningkat setelah diberi intervensi (Amelia, R. A., Winarto, W., Hadi, P., \& Lestari, E. S. 2020; Warwuru, P. M. 2019).

Menurut data yang diperoleh dari penulis bahwa pada tahun 2020 terdapat kejadian healthcare associated infections (HAIS) di RSUD Mayjend.H.M Ryacudu Lampung Utara di ruang rawat inap sebesar $2.3 \%$. Terjadi dengan limbah benda tajam sebesar $67.5 \%$ dan sarana kebersihan sebesar 55\%. Selain itu, angka kejadian dalam kepatuhan cuci tangan sebesar 67.5\%, sedangkan angka kejadian saat penggunaan APD didapatkan data sebesar 66\% (RSUD Mayjend.H.M Ryacudu Lampung Utara).

Healthcare

Associated Infecetions (HAIS) adalah infeksi terjadi / didapatkan dirumah sakit berkaitan atas pemberian pelayanan kesehatan. Mencegah Healthcare Associated Infecetions (HAIS) atas cara mencuci tangan, menggunakan alat pelindung diri, mengelola alat kesehatan, melakukan perawatan serta penutupan atas luka serta penegelolaan sampah. Salah satu cara paling efektif memutuskan rantai transmisi penyakit infeksi atas cara mengimplementasikan cuci tangan benar atas momen serta cara tepat sesuai atas kewasatasan standar (Madjid, T., \& Wibowo, A. 2019; SARI, N. 2020;

Widodo, A., \& Yusuf, E. 2017; Attoriq, S., \& Sodik, M. A. 2018). Upaya teruntuk mencegah terjadinya infeksi nosokomial salah satunya atas cara mencuci tangan. Mencuci tangan menurut Institut Pengendalian Infeksi (PPI), ini adalah prosedur pembersihan tangan dengan sabun atau antiseptik pada air keran, yang tujuannya untuk menghilangkan kotoran dari kulit dan mengurangi jumlah mikroorganisme. Kepatuhan 
cuci tangan sangat penting karena jika cuci tangan tidak dipatuhi maka dapat menimbulkan dampak seperti, pasien dapat memperpanjang perawatan atas penambahan diagnosa, pengunjung dapat menulari orang lain setelah meninggalkan rumah sakit, serta atas perawat akan membawa kuman untuk pasien lain serta diri sendiri (Riani, R., \& Syafriani, S. 2019; Nisa, K. 2020; Dewi, A. C. 2021).

Berdasarkan hasil presurvey bahwa fasilitas kesehatan mendukung kepatuhan perawat didalam menjalankan SOP cuci tangan belum cukup memadai, seperti contoh diruang bedah tidak ada tempat cuci tangan khusus ata wastafel cuci tangan, sehingga saat ingin mencuci tangan harus kekamar mandi terlebih dahulu. Dari 7 perawat ada di ruang bedah 4 Perawat tidak mencuci tangan terlebih dahulu sebelum melakukan tindakan keperawatan serta dari 7 perawat ada diruangan bedah terdapat 2 perawat tidak menggunakan APD / handscond saat akan membenarkan infus pasien.

Penggunaan APD dilakukan teruntuk Lindungi kulit dan selaput lendir dari bahaya dan paparan darah, cairan tubuh, sekret, kulit tidak lengkap, dan selaput lendir dari pasien ke staf. Jika dilakukan tindakan untuk melindungi tubuh dan selaput lendir dari percikan darah atau cairan tubuh, alangkah baiknya, darah atau cairan tubuh ini akan terkontaminasi dari pasien ke petugas. Maka dari itu perawat menggunakan APD seperti Sarung tangan, masker, kaca mata pelindung, masker atau pelindung wajah, topi, gaun atau celemek, serta sandal (Suharto, S., \&
Suminar, R. 2017; Rahayu, S., Yuliwar, R., \& Sulasmini, S. 2018).

Berdasarkan latar belakang di atas, peneliti tertarik untuk melakukan penelitian "Hubungan kepatuhan cuci tangan dan penggunaan APD perawat dengan resiko kejadian healthcare associated infections ( HAIS) pada masa pandemi covid-19 di RSUD Mayjend. H.M Ryacudu kabupaten lampung utara.

\section{METODOLOGI PENELITIAN}

Jenis penelitian yang digunakan dalam penelitian ini memiliki relevansi deskriptif dengan desain penelitian cross sectional. Populasi penelitian ini adalah seluruh perawat diruang rawat inap ruang kebidanan, ruang anak (perinatalogi dan NICU), ruang bedah, dan ruang penyakit dalam di RSUD Mayjend. H.M Ryacudu Lampung Utara Besar sampel untuk penelitian ini adalah 60 responden dan teknik pengambilan sampel yang digunakan adalah teknik total sampling. Penelitian ini dilaksnakan pada tanggal 25 Juni sampai 2 Juli 2021.

Alat ukur/instrumen tersebut berupa kuesioner. Validitas dan reliabilitas kuesioner yang digunakan oleh peneliti telah diuji, sehingga peneliti tidak melakukan pengujian ulang validitas dan reliabilitas Penelitian Purnomo, M., Siswanti, H., \& Prayitno, A. (2019) yang berjudul "hubungan kepatuhan cuci tangan perawat dengan HAIS Hasil akhir dari analisis menggunakan uji chi-squere didapat nilai P-value 0.000. Penelitian Rahmatilah, S. (2020). 
HASIL DAN PEMBAHASAN

Analisis Univariat

Distribusi Frekuensi Kepatuhan Cuci Tangan dan penggunaan APD Perawat Dengan Resiko Kejadian Healthcare Associated Infections (HAIS) Pada Masa Pandemi Covid-19 Di RSUD Mayjend. H.M. Ryacudu Lampung Utara Tahun 2021

\begin{tabular}{c|c|c}
\hline Kepatuhan Cuci Tangan & Frekuensi & Persentase (\%) \\
\hline Baik & 36 & $60.0 \%$ \\
\hline Kurang baik & 24 & $40.0 \%$ \\
\hline Total & 60 & $100 \%$ \\
\hline Penggunaan APD & Frekuensi & Persentase (\%) \\
\hline Baik & 41 & $68.3 \%$ \\
\hline Kurang baik & 19 & $31.7 \%$ \\
\hline Total & 60 & $100 \%$ \\
\hline Resiko HAIS & Frekuensi & Persentase (\%) \\
\hline Baik & 25 & $41.7 \%$ \\
\hline Kurang baik & 35 & $31.7 \%$ \\
\hline Total & 60 & $100 \%$ \\
\hline
\end{tabular}

Berdasarkan tabel, didapatkan dari 60 responden terdapat 36 responden $(60.0 \%)$ dengan nilai kepatuhan cuci tangan baik, sedangkan 24 responden (40.0\%) dengan nilai kepatuhan cuci tangan kurang baik. Berdasarkan tabel, dapat diketahui hasil penelitian dari 60 responden, 41 responden $(68.3 \%)$ merupakan penggunaan APD baik. Sedangkan, 19 responden $(31.7 \%)$

\section{Analisa Bivariat}

Hubungan Kepatuhan Cuci Tangan Perawat Dengan Resiko Kejadian Healthcare Associated Infections (HAIS) Pada Masa Pandemi Covid-19 Di RSUD Mayjend. H.M. Ryacudu Lampung Utara Tahun 2021

\begin{tabular}{|c|c|c|c|c|c|c|c|c|}
\hline \multirow{3}{*}{$\begin{array}{l}\text { Cuci } \\
\text { Tangan }\end{array}$} & \multicolumn{5}{|c|}{ Resiko HAIS } & & \multirow{3}{*}{$\begin{array}{c}\text { P- } \\
\text { Value }\end{array}$} & \multirow{3}{*}{ OR } \\
\hline & \multicolumn{2}{|c|}{ Baik } & \multicolumn{2}{|c|}{ Kurang } & \multicolumn{2}{|c|}{ Total } & & \\
\hline & $\mathrm{N}$ & $\%$ & $\mathrm{~N}$ & $\%$ & $\mathrm{~N}$ & $\%$ & & \\
\hline Baik & 11 & 18.3 & 25 & 41.7 & 36 & 60.0 & 0.033 & 0.134 \\
\hline Kurang & 14 & 23.3 & 10 & 16.7 & 24 & 40.0 & & $(0.107$ \\
\hline Total & 25 & 41.7 & 35 & 58.3 & 60 & 100 & & $0.923)$ \\
\hline
\end{tabular}

Berdasarkan tabel dapat dilihat responden dengan pengaruh cuci tangan kurang baik sebanyak 14 responden (23.3\%), dengan penerapan resiko kejadian dengan penggunaan APD yang kurang baik.

Berdasarkan tabel didapatkan hasil penelitian dari 60 responden, 25 responden $(41.7 \%)$ dengan resiko kejadian healthcare associated infections (HAIS) baik. Sedangkan, 35 responden $(58.3 \%)$ dengan resiko kejadian healthcare associated infections (HAIS) yang kurang baik.

healthcare associated infections (HAIS) kurang baik sebanyak 10 responden (16.7\%) dan resiko kejadian healthcare associated infections (HAIS) kurang baik 
sebanyak $24 \quad(40.0 \%)$ responden, sedangkan cuci tangan yang baik sebanyak 11 responden $(18.3 \%)$, dengan penerapan resiko kejadian healthcare associated infections (HAIS) baik 25 responden $(41.7 \%)$ dan resiko kejadian healthcare associated infections (HAIS) yang baik 36 responden $(60.0 \%)$.

Hasil uji statistic dengan uji chisquere didapatkan nilai $\mathrm{P}$-value
$0.033(<0.05)$ yang artinya ada hubungan kepatuhan mencuci tangan perawat dengan resiko kejadian healthcare associated infections (HAIS) Di RSUD Mayjend. H.M. Ryacudu Lampung Utara, dengan nilai $\mathrm{OR}=0.314$ artinya responden memiliki peluang terhadap resiko kejadian HAIS yang baik.

Hubungan Penggunaan APD Perawat Dengan Resiko Kejadian Healthcare Associated Infections (HAIS) Pada Masa Pandemi Covid-19 Di RSUD Mayjend. H.M. Ryacudu Lampung Utara

\begin{tabular}{|c|c|c|c|c|c|c|c|c|}
\hline \multirow{3}{*}{$\begin{array}{l}\text { Penggunaan } \\
\text { APD }\end{array}$} & \multicolumn{4}{|c|}{ Resiko HAIS } & & & \multirow{3}{*}{ P-Value } & \multirow{3}{*}{ OR } \\
\hline & \multicolumn{2}{|c|}{ Baik } & \multicolumn{2}{|c|}{ Kurang } & \multicolumn{2}{|c|}{ Total } & & \\
\hline & $\mathrm{N}$ & $\%$ & $\underline{N}$ & -\% & $\underline{N}$ & $\%$ & & \\
\hline Baik & 15 & 25.0 & 26 & 41.3 & 41 & 68.3 & 0.241 & 0.519 \\
\hline Kurang & 10 & 16.7 & 9 & 15.0 & 19 & 31.7 & & (0.172 - \\
\hline Total & 25 & 41.7 & 35 & 58.3 & 60 & 100 & & 1.563) \\
\hline
\end{tabular}

Berdasarkan tabel responden dengan penggunaan APD kurang baik sebanyak 10 responden $(16.7 \%)$, dengan resiko kejadian healthcare associated infections (HAIS) kurang baik sebanyak 9 responden $(15.0 \%)$ dan resiko kejadian healthcare associated infections (HAIS) yang kurang baik 19 responden (31.7\%). Sedangkan penggunaan APD baik sebanyak 15 responden (25.0\%), dengan resiko kejadian healthcare associated infections (HAIS) kurang baik 26 responden (43.3\%) dan resiko kejadian healthcare associated infections (HAIS) yang baik 41 responden (68.3\%).

Hasil uji statistic dengan uji chisquere didapat nilai P-value 0.241 (> 0.05) artinya tidak ada hubungan penggunaan APD untuk Perawat yang berisiko untuk infeksi terkait Kesehatan (HAIS) Di RSUD Mayjend. H.M. Ryacudu Lampung Utara, nilai $\mathrm{OR}=0.519$ artinya responden memiliki peluang terdapat resiko kejadian healthcare associated infections (HAIS) yang baik. 
Hubungan Kepatuhan Cuci Tangan Perawat Dengan Resiko Kejadian Healthcare Associated Infections (HAIS) Pada Masa Pandemi Covid19 Di RSUD Mayjend. H.M. Ryacudu Lampung Utara

Hasil analisis menggunakan chissquare, di dapat P-Value 0.033 sehingga $P$-Value $<a \quad(0.033<0.05)$ maka $\mathrm{Ha}$ diterima. Dapat disimpulkan ada hubungan kepatuhan mencuci tangan perawat dengan resiko kejadian HAIS di RSUD Mayjend. H.M. Ryacudu Lampung Utara Tahun 2021. Dari analisis di peroleh pula nilai Oods Ration 0.314 (0.107-0.923) artinya responden dengan kepatuhan cuci tangan perawat mempunyai peluang 0.314 untuk menghasilkan resiko kejadian healthcare associated infections (HAIS) tidak ingin.

Penelitian ini sejalan dengan penelitian Purnomo, M., Siswanti, H., \& Prayitno, A. (2019) yang berjudul "hubungan kepatuhan cuci tangan perawat dengan HAIS". Dari hasil analisis menunjukan Didapatkan sebanyak 36 responden mengamati cuci tangan, sebanyak

27 responden belum pernah mengalami HAIS (100\%), dan diantara 36 responden terdapat 9 responden yang tidak mematuhi cuci tangan, dan 1 responden $(11,1 \%)$. ) belum pernah mengalami infeksi, dan sebanyak 8 responden $(88,9 \%)$ pernah mengalami infeksi nosokomial. Hasil akhir dari analisis menggunakan uji chi-squere didapat nilai P-value 0.000. Bahwa nilai Pvalue $(0.000<$ nilai a 0.05) maka dapat disimpulkan bahwa ada hubungan antara kepatuhan kepatuhan cuci tangan perawat dengan kejadian infeksi rumah sakit.

Mencuci tangan adalah membasuh semua kotoran yang ada di tangan dengan beberapa cara sesuai kebutuhan, mulai dari ujung jari hingga siku dan lengan. Kebersihan tangan adalah teknik dasar yang paling penting untuk mencegah dan mengendalikan infeksi (Kausar, A. 2017).

Berdasarkan hasil analisa peneliti yang dilakukan pada perawat RSUD Mayjend. H.M. Ryacudu Lampung Utara didapatkan bahwa besarnya signifikasi adalah $0.033<0.05$ hal ini menjawab hipotesis apabila tingkat signifikan $<0.05 \mathrm{Ha}$ diterima. Maka, dapat dinyatakan bahwa ada hubungan kepatuhan cuci tangan perawat dan resiko kejadian HAIS di RSUD Mayjend. H.M. Ryacudu Lampung Utara. Penyebab terjadinya ada Hubungan antara kepatuhan mencuci tangan perawat dan risiko infeksi terkait perawatan kesehatan (HAIS) yaitu dikarenakan perawat tidak patuh terhadap cuci tangan.

Hubungan Penggunaan APD Perawat Dengan Resiko Kejadian Healthcare Associated Infections (HAIS) Pada Masa Pandemi Covid19 Di RSUD Mayjend. H.M. Ryacudu Lampung Utara Tahun 2021

Hasil analisis menggunakan chisquare, di dapat $P$-Value 0.241 sehingga $P$-Value $<a \quad(0.241>0.05)$ maka Ho ditolak. Dapat disimpulkan tidak ada hubungan penggunaan APD perawat dengan resiko kejadian healthcare associated infections (HAIS) di RSUD Mayjend. H.M. Ryacudu Lampung Utara Tahun 2021. Dari hasil analisis didapatkan nilai Oods Ratio 0.519 artinya responden dan penggunaan APD mempunyai peluang 0.519 untuk terjadi resiko kejadian HAIS yang tidak diinginkan.

Penelitian ini sejalan dengan penelitian Rahmatilah, S. (2020) dengan judul "pengaruh perilaku dan kepatuhan perawat terhadap 
penggunaan alat pelindung diri dalam pencegahan infeksi nosokomial". Dari analisis diketahui bahwa perawat yang patuh sebanyak 23 perawat (44.2\%) menggunakan APD lengkap dan 29 perawat $(55.8 \%)$ tidak menggunakan APD lengkap. Meskipun perawat tidak begitu patuh 3 perawat $(60 \%)$ menggunakan APD lengkap dan 2 perawat (40\%) tidak menggunakan APD lengkap. Hasil akhir dari uji statistik didapatkan nilai $p 0.651>$ 0.05 Oleh karena itu, dapat disimpulkan bahwa tidak relevan bagi perawat untuk mengamati penggunaan alat pelindung diri untuk mencegah terjadinya infeksi nosokomial.

Alat Pelindung Diri atau APD adalah alat yang digunakan untuk melindungi diri atau tubuh dari bahaya kecelakaan kerja, dapat mengurangi tingkat keparahan kecelakaan kerja, tetapi tidak dapat menghilangkan atau mengurangi bahaya yang ada. APD digunakan untuk melindungi tenaga medis dari risiko kontak dengan cairan tubuh pasien, seperti darah pasien, sekret, ekskreta, kulit tidak lengkap dan selaput lendir. APD diperlukan untuk melakukan operasi berisiko tinggi, seperti pemeriksaan rutin, pembedahan, otopsi, atau perawatan gigi yang menggunakan bor berkecepatan tinggi (Dewi, 2019).

Berdasarkan hasil analisa peneliti yang dilakukan pada perawat $\mathrm{Di}$ RSUD Mayjend. H.M. Ryacudu Lampung Utara Tahun 2021, dapat diketahui bahwa besarnya signifikan adalah $0.241(0.241>0.05)$. Hal ini menjawab hipotesis apabila tingkat signifikan > 0.05 Ho ditolak. Maka dapat dinyatakan tidak ada hubungan penggunaan APD perawat dengan resiko kejadian healthcare associated infections (HAIS) di ruang rawat inap RSUD Mayjend. H.M. Ryacudu Lampung Utara .
Penyebab tidak adanya hubungan penggunaan APD perawat dengan resiko kejadian HAIS yaitu karena perawat menggunakan alat pelidung diri saat melakukan tindakan ataupun kontak langsung dengan pasien.

\section{KESIMPULAN}

Bahwa yang menerapkan kepatuhan mencuci tangan yang baik 25 responden $(41.7 \%)$ dan yang kurang baik 35 responden (58.3\%). Berdasarkan variable penggunaan APD nilai terbaik 25 responden (41.7\%) dan yang kurang baik 35 respoden (58.3\%) sehingga dapat disimpulkan terdapat hubungan pengaruh mencuci tangan dan tidak ada hubungan penggunaan APD dengan resiko kejadian healthcare associated infections (HAIS) di ruang rawat inap RSUD Mayjend. H.M. Ryacudu Lampung Utara Tahun 2021

\section{DAFTAR PUSTAKA}

Amelia, R. A., Winarto, W., Hadi, P., \& Lestari, E. S. (2020). Kepatuhan Cuci Tangan Petugas Rawat Inap Di Rumah Sakit Nasional Diponegoro Semarang. Diponegoro Medical Journal (Jurnal Kedokteran Diponegoro), 9(3), 301-312.

Amin, M., Saleh, A. M., \& Bilfaqih, H. Z. A. (2020). Covid-19 (Corona Virus Disease 2019): Tinjauan Perspektif Keilmuan Biologi, Sosial, dan Agama. Inteligensia Media.

Anggreni, D., \& Safitri, C. A. (2020). Hubungan Pengetahuan Remaja Tentang Covid-19 Dengan Kepatuhan Dalam Menerapkan Protokol Kesehatan Di Masa New Normal. Hospital Majapahit (Jurnal Ilmiah Kesehatan Politeknik Kesehatan Majapahit Mojokerto), 12(2), 134-142. 
Attoriq, S., \& Sodik, M. A. (2018). Pencegahan Dan Pengendalian Infeksi Terkait Pelayanan Kesehatan Di Lahan Praktik.

Dewi, A. C. (2021). Hubungan Supervisi IPCN (Infection Prevention Control Nurse) dengan Kepatuhan Perawat Melaksanakan Hand Hygiene Di Instalasi Rawat Inap RSU Mitra Delima.

Fitriyana, N. (2020). God Spot dan Tatanan New Normal di Tengah Pandemi Covid-

19. Jurnal Ilmu Agama: Mengkaji Doktrin, Pemikiran, Dan Fenomena Agama, 21(1), 1-24.

Handayani, D., Hadi, D. R., Isbaniah, F., Burhan, E., \& Agustin, H. (2020). Penyakit Virus Corona 2019. Jurnal Respirologi Indonesia, 40(2), 119-129.

Hasanah, R. (2020). Asumsi masyarakat mengenai keselamatan pasien pada masa covid 19 di rumah sakit.

Indarta, D. W. (2019). Perlindungan Hukum Pasien Sebagai Konsumen Jasa Dalam Pelayanan Kesehatan (Studi Di Rumah Sakit Ibnu Sina Bojonegoro). JustitiableJurnal Hukum, 1(2), 85-116.

Isnainy, U. C. A. S., Zainaro, M. A., Novikasari, L., Ariyanti, L., \& Furqoni, P. D. (2020). Pendidikan Kesehatan Tentang Perilaku Hidup Bersih Dan Sehat (PHBS) di SMA Negeri 13 Bandar Lampung. Jurnal Kreativitas Pengabdian Kepada Masyarakat (PKM), 3(1), 27-33.

Khoirudin, P., Zainaro, M. A., \& Andoko, A. (2021). Pengetahuan dan beban kerja perawat dengan penerapan kewaspadaan standar di RSUD Dr. A. Dadi Tjokrodipo Bandar
Lampung. Holistik Jurnal Kesehatan, 15(3), 499-506.

Madjid, T., \& Wibowo, A. (2019). Analisis Penerapan Program Pencegahan Dan Pengendalian Infeksi Di Ruang Rawat Inap Rsud Tebet Tahun 2017. Jurnal Administrasi Rumah Sakit Indonesia, 4(1).

Nisa, K. (2020). Kebijakan Rumah Sakit Dalam Upaya Pencegahan Penyakit Infeksi Bagi Pasien Dan Tenaga Kesehatan Di Lingkungan Rumah Sakit.

Purnomo, M., Siswanti, H., \& Prayitno, A. (2019). Hubungan Kepatuhan Cuci Tangan Perawat Dengan Hais Di Ruang Gading Rsud Soewondo. The 9th University Research Colloqium (Urecol), 9(1).

Rahayu, S., Yuliwar, R., \& Sulasmini, S. (2018). Hubungan Pengetahuan Dan Sikap Perawat Dengan Tindakan Pemasangan Infus Diruang Rawat Inap Dahlia Rsi Gondanglegi Malang. Nursing News: Jurnal Ilmiah Keperawatan, 3(3).

Rahmatilah, S. (2020). Pengaruh Perilaku Dan Kepatuhan Perawat Terhadap Penggunaan Alat Pelindung Diri Dalam Pencegahan Infeksi Nosokomial Di Ruang Rawat Inap Rsud Dr. R. M Djoelham Binjai Tahun 2020. Journal Of Healthcare Technology And Medicine, 6(2), 1142-1157.

Riani, R., \& Syafriani, S. (2019). Hubungan Antara Motivasi Dengan Kepatuhan Perawat Melaksanakan Handhygiene Sebagai Tindakan Pencegahan Infeksi Nosokomial Di Ruang Rawat Inap Rumah Sakit Ah Tahun 2019. Jurnal Ners, 3(2), 49-59.

Sari, N. (2020). Hadapi Infeksi Nosokomial Dengan Hand 
Hygiene Akibat Kecelakaan

Kerja Perawat Dalam

Pemberian Asuhan

Keperawatan Di Rumah Sakit.

Suharto, S., \& Suminar, R. (2017).

Hubungan Pengetahuan Dan

Sikap Perawat Dengan

Tindakan Pencegahan Infeksi

Di Ruang ICu Rumah

Sakit. Jurnal Riset Hesti

Medan Akper Kesdam I/Bb Medan, 1(1), 1-9.

Trisnantoro, L. (2018). Memahami penggunaan ilmu ekonomi dalam manajemen rumah sakit. UGM press.

Wahyuni, D., Sururuddin, S., \& Nugroho, A. $\quad S$. (2021). Persepsi Masyarakat Terhadap Berita-Berita Covid19 Di Media Sosialfacebook (Studi Desa Sungai Puar Kecamatan Mersam Kabupaten Batanghari) (Doctoral

Dissertation, Uin Sulthan Thaha Saifuddin Jambi).

Warwuru, P. M. (2019). Hubungan Kepatuhan Perawat Dalam Melaksanakan Cuci Tangan Enam Langkah Lima Momen Dengan Kejadian Phlebitis Di Rumah Sakit Umum Pancaran Kasih Gmim Manado. Graha Medika Nursing Journal, 2(1), 19-26.

Widodo, A., \& Yusuf, E. (2017). Pengaruh Pemberian Pendidikan Kesehatan Tentang Infeksi Nosokomial Terhadap Kepatuhan Penggunaan Alat Pelindung Diri (APD) Pada Cleaning Service di RS Aisyiyah Bojonegoro. Jurnal Hospital Science, 1(1).

Zainaro, A., Gunawan, R., \& Mardani, M. (2021). Hubungan Perilaku Dan Sikap Perawat Terhadap Upaya Pencegahan HAls Di Ruang Rawat Inap RSUD Mayjend HM Ryacudu Kota Bumi Lampung Utara Tahun 2020. Jurnal IImu
Keperawatan Indonesia, 2(1), 40-52. 